\title{
12. POTASSIUM-ARGON AGES ON BASALTIC ROCKS RECOVERED FROM DSDP LEG 22, INDIAN OCEAN
}

\author{
Ian McDougall, Australian National University, Canberra, Australia
}

\section{INTRODUCTION}

Physical age measurements on samples from the ocean basins can provide useful information on the time scale of evolution of the basins. Such data are particularly desirable to supplement and validate extrapolations made to the physical time scale from marine magnetic anomaly profiles and paleontological studies. Isotopic ages may be determined in favorable cases on igneous material such as volcanic ash in the sedimentary sequences or from igneous rocks, most commonly basaltic, forming the basement or interbedded with sediments.

The K-Ar dating method is perhaps the most useful means of physical dating of samples from the ocean basins, but considerable difficulties are encountered in applying the method. These difficulties arise because of the nature of the samples and because of the environment in which many of the rocks have crystallized. Doubt commonly exists as to whether all preexisting radiogenic argon was lost at the time of crystallization, particularly if this occurred under high hydrostatic pressure. Glass, a common component of oceanic volcanics, often retains radiogenic argon poorly, particularly if alteration or devitrification of the glass has occurred. Reliable age measurements can rarely be obtained on weathered or altered rocks because radiogenic argon commonly leaks from such samples.

For the present study, nine core samples of basalt from near the bottom of the holes drilled at Sites 211,214,215, and 216 were made available for possible dating. Each sample was examined in thin section; five were found to be quite unsuitable for K-Ar dating because of extensive low temperature alteration. The remaining four samples were considered worth attempting to date, although none was regarded as ideal. Two samples were measured as whole rocks by the conventional $\mathrm{K}-\mathrm{Ar}$ method employing isotope dilution argon determination and potassium measurement by flame photometry using techniques described previously (McDougall et al., 1969). The other two samples were determined by the $\mathrm{Ar}^{40} / \mathrm{Ar}^{39}$ method by the total fusion technique (Merrihue, 1965; Mitchell, 1968). This method involves irradiation of the sample in a fast neutron flux (in the present case in the core facility of the HIFAR reactor of the Australian Atomic Energy Commission). A proportion of the $\mathrm{Ar}^{40}$ is converted to $\mathrm{Ar}^{39}$ by the fast neutrons. Argon extracted from the samples is measured isotopically in a mass spectrometer and compared with ratios obtained from a standard sample of known age irradiated at the same time. These data enable an age to be calculated on a single aliquot of sample, thus overcoming difficulties of obtaining representative aliquots of inhomogeneous samples. A full description of the techniques employed will be given elsewhere. Results of the age determinations are listed in
Tables 1 and 2. Geological information was obtained primarily from the preliminary report on Leg 22 (von der Borch, Sclater, et al., 1972).

\section{RESULTS AND DISCUSSIONS}

Site 211

At this site, to the south of the Java Trench, a sequence of sediments about 430 meters thick was drilled overlying weathered basalt. Two samples of coarse-grained doleritic rock were provided from Core 12 at a depth of about 411 meters. These two samples are from a 10-meter-thick sill which is intrusive into Late Cretaceous (Campanian) sediments. The two doleritic basalt samples were 1.7 meters apart and consisted of titanaugite, plagioclase, alteration after olivine, iron oxide, various other cryptocrystalline alteration products, and sheaves of zeolite. Both samples were considered unsuitable for $\mathrm{K}-\mathrm{Ar}$ dating as whole rock. However, each rock contained about $2 \%$ of small flakes of red brown biotite which we attempted to separate. Approximately $0.5 \mathrm{~g}$ of biotite concentrate was obtained from each sample; Laboratory sample $72-556$ was about $75 \%$ purity and $72-557$ about $65 \%$ purity, clinopyroxene being the main impurity. Because of the very limited amount of concentrate available and the great difficulty of obtaining representative aliquots, it was decided to measure their age by the $\mathrm{Ar}^{40} / \mathrm{Ar}^{39}$ technique in which the argon and potassium are effectively measured on a single aliquot. Results are given in Table 1. The two biotite concentrates give ages agreeing to within experimental error; the mean age is $71 \pm 2$ m.y.

The Cretaceous-Tertiary boundary has an age of $65 \mathrm{~m} . \mathrm{y}$ (Berggren, 1972), and the age of the MaastrichtianCampanian boundary is estimated to lie at about $70 \mathrm{~m} . \mathrm{y}$. (Casey, 1964). Thus the measured age of $71 \pm 2$ m.y. for the diabase sill would be regarded as late Campanian. The sediments intruded by this sill are given as early Campanian to early Maastrichtian on the basis of the contained nannofossils. These data are all remarkably concordant provided that the sill was emplaced very soon after the deposition of the adjacent sediments and provided that the Maastrichtian-Campanian boundary is at least $71 \pm 2 \mathrm{~m} . \mathrm{y}$. old. The K-Ar data amply confirm the Late Cretaceous age for the lower part of the sedimentary sequence at Site 211.

\section{Site 214}

Drilling at this site, located on the crest of the Ninetyeast Ridge, penetrated to a depth of 500 meters, passing through fossiliferous oozes of Pleistocene to Eocene age to 330 meters, underlain by a sequence of sediments indicating shallow water deposition, and containing some basalt flows. These latter sediments are given as possible 
TABLE 1

Total Fusion $\mathrm{Ar}^{40} / \mathrm{Ar}^{39}$ Ages on Biotites Separated from Coarse Basaltic Rocks from Site 211, south of Java Trench

\begin{tabular}{|c|c|c|c|c|c|c|c|c|c|c|}
\hline Sample & Lab No. & Material & $\mathrm{Ar}^{40} / \mathrm{Ar}^{39}$ & $\mathrm{Ar}^{37} / \mathrm{Ar}^{39^{\mathrm{a}}}$ & $\mathrm{Ar}^{36} / \mathrm{Ar}^{39}$ & $\mathbf{J}$ & $\begin{array}{c}\mathrm{Ar}_{\mathrm{rad}}^{40} \\
(\%)\end{array}$ & $\begin{array}{c}\mathrm{Ar}_{\mathrm{Ca}}^{36} \\
(\%)\end{array}$ & $\begin{array}{c}{ }^{\mathrm{Ar}_{\mathrm{Ca}}^{39}} \\
(\%)\end{array}$ & $\begin{array}{l}\text { Calculated } \\
\text { Age (m.y.) } \\
\pm 2 \text { s.d. }\end{array}$ \\
\hline $12-1,22-24 \mathrm{~cm}$ & $72-556$ & $\begin{array}{l}\text { Impure biotite } \\
\text { from basalt }\end{array}$ & $\begin{array}{l}46.2 \\
41.2\end{array}$ & $\begin{array}{l}0.589 \\
0.547\end{array}$ & $\begin{array}{l}0.0488 \\
0.0287\end{array}$ & $\begin{array}{l}0.00123 \\
0.00123\end{array}$ & $\begin{array}{l}68.8 \\
79.5\end{array}$ & $\begin{array}{l}0.4 \\
0.6\end{array}$ & $\begin{array}{l}<0.1 \\
<0.1\end{array}$ & $\begin{array}{l}71.2 \pm 5.1 \\
73.2 \pm 5.6\end{array}$ \\
\hline \multirow[t]{2}{*}{$12-2,40-44 \mathrm{~cm}$} & $72-557$ & $\begin{array}{l}\text { Impure biotite, } \\
\text { from basalt }\end{array}$ & 59.8 & 0.777 & 0.0982 & 0.00123 & 51.6 & 0.2 & $<0.1$ & $69.2 \pm 5.9$ \\
\hline & GA 1550 & $\begin{array}{l}\text { ANU standard } \\
\text { biotite }\end{array}$ & $\begin{array}{l}49.0 \\
45.8\end{array}$ & $\begin{array}{l}0.0175 \\
0.0130\end{array}$ & $\begin{array}{l}0.0160 \\
0.0149\end{array}$ & $(0.00123)$ & $\begin{array}{l}90.3 \\
90.4\end{array}$ & $\begin{array}{l}<0.1 \\
<0.1\end{array}$ & $\begin{array}{l}<0.1 \\
<0.1\end{array}$ & $\begin{array}{l}(95.5) \\
(95.5)\end{array}$ \\
\hline
\end{tabular}

${ }^{\mathrm{a}}$ Corrected for $\mathrm{Ar}^{37}$ decay

$\lambda_{\mathrm{e}}=0.585 \times 10^{-10} \mathrm{yr}^{-1} ; \lambda_{\beta}=4.72 \times 10^{-10} \mathrm{yr}^{-1} ; \mathrm{K}^{40} / \mathrm{K}=1.19 \times 10^{-2}$ atom $\%$

TABLE 2

Potassium-Argon Ages on Basalt Samples from Ninetyeast Ridge

\begin{tabular}{|c|c|c|c|c|c|c|}
\hline Sample & Lab No. & Material & $\underset{(w t \%)}{K}$ & $\begin{array}{c}\text { Rad. } \mathrm{Ar}^{40} \\
\left(10^{-6} \mathrm{ccNTP} / \mathrm{g}\right)\end{array}$ & $\frac{\text { 100. Rad. } \mathrm{Ar}^{40}}{\text { Total } \mathrm{Ar}^{40}}$ & $\begin{array}{c}\text { Calculated } \\
\text { Age (m.y.) } \\
\pm 2 \text { s.d. }\end{array}$ \\
\hline $\begin{array}{l}214-48-1,76-83 \mathrm{~cm} \\
\text { Subbottom depth } 441.5 \mathrm{~m}\end{array}$ & $72-558$ & $\begin{array}{l}\text { Basalt, whole } \\
\text { rock }\end{array}$ & $1.241,1.244$ & $\begin{array}{l}2.709 \\
2.661\end{array}$ & $\begin{array}{l}90.0 \\
85.5\end{array}$ & $\begin{array}{l}53.9 \pm 0.8 \\
52.9 \pm 0.8\end{array}$ \\
\hline $\begin{array}{l}216-37-4,58-62 \mathrm{~cm} \\
\text { Subbottom depth } 467.5 \mathrm{~m}\end{array}$ & $72-559$ & $\begin{array}{l}\text { Basalt, whole } \\
\text { rock }\end{array}$ & $0.4076,0.4078$ & $\begin{array}{l}1.041 \\
1.074 \\
1.066\end{array}$ & $\begin{array}{l}63.3 \\
42.0 \\
43.3\end{array}$ & $\begin{array}{l}62.9 \pm 1.2 \\
64.9 \pm 2.0 \\
64.4 \pm 1.4\end{array}$ \\
\hline
\end{tabular}

$\lambda_{\mathrm{e}}=0.585 \times 10^{-10} \mathrm{yr}^{-1} ; \lambda_{\beta}=4.72 \times 10^{-10} \mathrm{yr}^{-1} ; \mathrm{K}^{40} / \mathrm{K}=1.19 \times 10^{-2}$ atom $\%$

Paleocene, with definite Paleocene and Eocene above. Altered basalt at a depth of 490 meters is possibly basement.

A sample from a basalt flow interbedded with sediments at a depth of 441.5 meters was thought to be fresh enough to attempt K-Ar dating. The basalt has a slightly fluidal texture owing to alignment of plagioclase laths, between which occur small grains of clinopyroxene and iron oxide. Intersertally there is about $10 \%$ of pale brown, virtually isotropic, glass. Locally there are patches of a yellow mineraloid. Dating of this relatively potassium-rich basalt (72-558, Table 2) in duplicate as a whole rock sample yielded concordant ages averaging 53.4 m.y. The PaleoceneEocene boundary is given as 53.5 m.y. by Berggren (1972). As the dated basalt is thought to come from a flow interbedded with sediments at least as old as Paleocene it would appear that some loss of radiogenic argon from the sample may have occurred. A sample of basalt at a depth of 491 meters, unfortunately, was much too altered to carry out dating.

\section{Site $\mathbf{2 1 6}$}

This site was drilled on the crest of the Ninetyeast Ridge near the equator and some $10^{\circ}$ north of Site 214. A total of 457 meters of sediments was penetrated with vesicular basalts forming the remaining 20 meters drilled. The lowest 100 meters of sediment is late Maastrichtian in age from the palaeontology and was deposited in shallow water.
A sample of basalt from Core 37 at a depth of 467.6 meters was thought to be sufficiently fresh to undertake a $\mathrm{K}$-Ar age measurement. The rock consists of rare plagioclase phenocrysts set in a fine-grained groundmass of plagioclase laths, clinopyroxene granules, iron oxide, about $10 \%$ of chloritic material, and a few percent of pale brown isotropic glass. This sample (72-559) was run as a whole rock and replicate measurements give a mean calculated age of $64.1 \pm 1.0$ m.y. (Table 2). The Maastrichtian-Danian (Cretaceous-Paleocene) boundary has an age of 65 m.y. (Berggren, 1972). The measured isotopic age of the basalt is close to this and suggests that the boundary may be slightly younger than the age given by Berggren (op. cit.). However, the possibility of argon loss cannot be ruled out.

\section{SUMMARY AND CONCLUSIONS}

The two biotite concentrates from the diabase sill near the bottom of the section at Site 211 give concordant results at 71 m.y., confirming the Late Cretaceous age for this part of the sequence and consistent with all other data from this site. These results were obtained using the $\mathrm{Ar}^{40} / \mathrm{Ar}^{39}$ technique and serve to illustrate the value of this method when limited material is available, particularly when the sample is inhomogeneous.

The two basalts, dated by the conventional K-Ar method as whole rock samples from near the bottom of holes at Sites 214 and 216 on the Ninetyeast Ridge yield measured 
ages that appear to be slightly too young by comparison with estimates derived from paleontological study of adjacent sediments. Some argon loss, presumably from the glass in these basalts, may have occurred in the sample from Site 214 (and possibly also in the 216 sample), which could be related to the low temperature alteration that had taken place in both samples. The paleontological data show that the basal sediments at Site 216 are older than at Site 214 to the south; the K-Ar results on the basalts at the two sites show the same trend. The character of the basal sediments suggests that they were deposited at shallow depth and the basalts also probably were erupted near sea level, minimizing the risk that radiogenic argon was trapped in the basalts at the time of crystallization. The age results are consistent with the view that to obtain reliable $\mathrm{K}-\mathrm{Ar}$ ages on basaltic rocks samples need to be unaltered and preferably free of glass.

\section{ACKNOWLEDGMENTS}

Thanks are extended to Drs. C. C. von der Borch and J. J. Veevers for supplying the core samples and for valuable discussions.

R. Rudowski made the biotite separations from the Site 211 samples and Z.Roksandic, R. Maier, and K. Phillips assisted with the $\mathrm{K}$-Ar measurements. The cooperation of the Australian Atomic Energy Commission in facilitating the irradiations for the $\mathrm{Ar}^{40} / \mathrm{Ar}^{39}$ work is acknowledged as is the Australian Institute of Nuclear Science and Engineering who defrayed the cost of irradiation through a grant.

\section{REFERENCES}

Berggren, W. A. 1972. A Cenozoic time-scale-some implications for regional geology and paleobiogeography: Lethaia, V. 5, p. 195-215.

Casey, R. 1964. The Cretaceous period: Quart. J. Geol. Soc. London, V. 120S, p. 193-202.

McDougall, I., Polach, H.A., and Stipp, J.J. 1969. Excess radiogenic argon in young subaerial basalts from the Auckland volcanic field, New Zealand: Geochim. Cosmochim. Acta, V. 33, p. 1485-1520.

Merrihue, C. M. 1965. Trace-element determinations and potassium-argon dating by mass spectroscopy of neutron-irradiated samples (abstract): Trans. Am. Geophys. Union, V. 46, p. 125.

Mitchell, J. G. 1968. The argon-40/argon-39 method for potassium-argon age determination: Geochim. Cosmochim. Acta, V. 32, p. 781-790.

von der Borch, C. C., Sclater, J. G., Gartner, Jr., S., Hekinian, R., Johnson, D. A., McGowran, B., Pimm, A. C., Thompson, R. W., and Veevers, J. J., 1972. Deep Sea Drilling Project Leg 22: Geotimes, v. 17, p. 15-17. 